\title{
TRANSPARANSI PENGELOLAAN ANGGARAN PENDAPATAN DAN BELANJA DESA DI DESA PERTASI KENCANA KECAMATAN KALAENA KABUPATEN LUWU TIMUR
}

\author{
Amirruddin ${ }^{1}$, Muhammadiah², Ruskin Azikin² \\ ${ }^{1}$ Program Studi Ilmu Pemerintahan Fakultas Ilmu Sosial dan Ilmu Politik \\ Universitas Muhammadiyah Makassar \\ Jl. Sultan Alauddin No. 259 Makassar 90221 \\ Telp. 0411-866972 ext.107.Fax.0411-8655888 \\ amiruddin@yahoo.co.id \\ ${ }^{2}$ Program Studi Ilmu Administrasi Negara Fakultas Ilmu Sosial dan Ilmu Politik \\ Universitas Muhammadiyah Makassar \\ Jl. Sultan Alauddin No. 259 Makassar 90221 \\ Telp. 0411-866972 ext.107.Fax.0411-8655888 \\ muhammadiah@unismuh.ac..id ruskinazikin@gmail.com
}

\section{ABSTRACT}

The purpose of this study is to determine the transparency of the funds in the Village pertasi Kencana Kalaena District Luwu Timur Regency and determine the maximum performance in terms of transparency in the management APBDesa research method used was qualitative, using the technique of interview results of this study indicate that the community had not experienced management transparency APBDesa Village Pertasi kencana Kalaena Luwu Timur subdistrict because people are not involved in it, and as for transparency iyu proved less than the maximum in because less easily accessible to the general public, especially villagers in Desa Kencana Pertasi Luwu District of Kalaena. This is caused due to problems such as not opening up government and not easily accessible so that people do not know about the budget being used, other than that transparency is often not eventuated as it should be because they lack the influence of village officials on the development and management of the allocation of funds this village becomes a limiting factor transparency of the management of revenue and expenditure budget Village in the Village pertasi Kencana Kalaena District Luwu Timur Regency of transparency when it is expected to increase creativity, prosperity and good cooperation.

Keywords : transparency, budget management, village

\section{ABSTRAK}

Tujuan penelitian ini yaitu untuk mengetahui transparansi dana di Desa Pertasi Kencana Kecamatan Kalaena Kabupaten Luwu Timur dan mengetahui maksimal kinerja dalam hal transparansi pengelolaan APBDesa metode penelitian yang digunakan adalah kualitatif menggunakan teknik wawancara hasil penelitian ini menunjukkan bahwa masyarakat belum merasakan transparansi pengelolaan APBDesa di Desa Pertasi kencana Kecamatan Kalaena Kabupaten Luwu Timur karena masyarakat kurang dilibatkan dalam hal itu dan adapun transparansi iyu terbukti kurang maksimal di karenakan kurang mudahnya diakses oleh masyarakat umum khususnya masyarakat desa di Desa Pertasi Kencana Kecamatan Kalaena Kabupaten Luwu. Hal ini disebabkan karena adanya masalah seperti tidak terbukanya pemerintah dan tidak mudahnya diakses sehingga masyarakat tidak mengetahui mengenai anggaran yang terpakai, selain itu trasparansi ini sering tidak terrealisasi sebagaimana mestinya kerena rendahnya pengaruh aparatur desa terhadap pengembangan dan pengelolaan alokasi dana desa ini menjadi faktor penghambat transparansi pengelolaan anggaran pendapatan dan belanja desa di Desa pertasi Kencana Kecamatan Kalaena Kabupaten Luwu Timur padahal dari transparansi ini diharapkan dapat meningkatkan kreativitas, kesejahteraan dan kerja sama yang baik.

Kata Kunci : Transparansi, Pengelolaan Anggaran, Desa 


\section{A. PENDAHULUAN}

Sejak awal dibentuknya negara Kesatuan Republik Indonesia oleh para oleh pendiri republik ini adanya daerah otonom dalam Negara Kesatuan Republik Indonesia (Zauhar : 1994). Pendiri negara ini telah menetapkan pilihannya pada prinsip pembagian kekuasaan dalam penyelenggaraan pemerintah negara.

Dengan demikian, sudah diamanatkan pada dasarnya semua tuntutan tersebut dimaksudkan untuk membangun budaya demokrasi di Indonesia. Lahirnya Undang-undang No. 22 Tahun 1999 tentang Pemerintah Daerah yang menggantikan Undang-Undang No. 5 Tahun 1974 yang dianggap lebih sesuai dengan aspirasi masyarakat di daerah dan daerah juga lebih mampu mewujudkan otonomi daerah.

Sejak dikeluarkannya Undang-Undang pemerintah daerah mulai dilaksanakan secara efektif pada bulan Januari 2001, telah membawa perubahan yang cukup berarti terhadap hubungan pusat dan daerah, terdapat beberapa kemajuan berarti terhadap hubungan pusat dan daerah. Kemajuan disini mempunyai artian seperti tingkat partisipasi masyarakat yang semakin luas dalam berbagai bidang, atau tingkat tanggung jawab pemerintah Kabupaten/Kota yang lebih besar kepada masyarakat. Meskipun demikian, masih banyak hal yang perlu dilakukan dan diperbaiki dalam pelaksanaan otonomi daerah

Hal ini dapat dilihat dalam proses Pembuatan Undang-Undang No. 22 Tahun 1999 yang sama sekali tidak melibatkan orang daerah dan lebih mengutamakan kepentingan pusat. Disamping itu masih banyak ketidak jelasan dan kurang keterbukaan bagaimana implementasi yang baik itu mesti dimulai (Salam, 2005:11). Maka dari itu perlu dilakukan perubahan terhadap Undang- Undang No. 22 Tahun 1999 yang dirasa belum mampu menjawab tantangan atau mengakomodasi tuntutan perkembangan masyarakat, dan ketatanegaraan yang ditinjau dari sisi daya guna dan hasil guna dalam penyelenggaraan pemerintah di daerah. Berdasar kondisi tersebut maka pemerintah memperbaiki Undang-Undang No. 22 Tahun 1999 tentang Pemerintah Daerah menjadi Undang-undang
No. 32 Tahun 2004 tentang Pemerintah Daerah, yang dilaksanakan secara efektif pada tanggal 15 Oktober 2004.

Menurut Dwiyanto, dkk (2003:106), bahwa transparansi international menempatkan Indonesia pada tahun 2002 di urutan ke-98 antara 102 negara. Dalam hal korupsi, hal ini terbukti bahwa masih tingginya tingkat korupsi yang terjadi di Indonesia baik dipusat maupun di daerah. Alternatif pemecahan masalah praktik KKN di pemerintahan daerah yaitu dapat dilakukan dengan mengutamakan upaya dalam bentuk perbaikan sistem pengawasan, perbaikan etika moral pegawai, dan pemberian peringatan atau sangsi.

Dari berbagai fenomena praktik KKN diatas maka dapat dikatakan bahwa Indonesia belum dapat mewujudkan suatu tata pemerintahan yang baik, sebab masih banyak terjadinya praktik KKN, maka dapat dipakai indikator dari buruknya pemerintahan di Indonesia saat ini karena rendahnya Transparansi pelayana maupun anggaran. Hal ini merupakan salah satu ciri penting dari tata pemerintahan yang baik (good governance).

Kepemerintahan yang baik (good governance) merupakan suatu tuntutan yang harus dipenuhi oleh Negara dalam rangka pencapaian tujuannya. Untuk itu penyelenggaraan pemerintahan yang diharapkan bukan lagi pemerintah yang "banyak memerintah" namun pemerintah yang "sedikit memerintah" atau "pemerintah yang baik" (better governance) menurut Osborne dan Gaebler dalam Widodo (2000:18). Dalam rangka penyelenggaraan good governance maka ketiga unsur yang berada dalam ruang governance harus dapat bekerja dengan baik. Unsur-unsur yang dimaksud tersebut adalah : state (Negara atau Pemerintahan), private sector (sektor swasta atau dunia usaha) dan society (masyarakat). Unsurunsur tersebut akan berinteraksi menurut fungsi-fungsi yang harus dilakukannya. Pada masa yang akan datang diperlukan kerja sama dari unsur tersebut agar pemerintah benar-benar mampumemerintah.

Dalam rangka menanggapi tuntutan pemerintah khususnya pada Sekretariat Daerah Kabupaten Luwu Timur harus 
memperbaiki kinerja birokrasi yang profesional guna meningkatkan pelayanan masyarakat. Dengan kinerja birokrasi yang lebih profesional dalam melayani masyarakat, maka proses pelayanan dapat dilaksanakan dengan baik. Dari pernyataan diatas kewenangan diberikan kepada daerah selanjutkan diberikan kepada pemerintah desa untuk dapat mengatur keuangan dan mengatur anggaran belanja pemerintah desa. Seperti halnya yang terjadi di desa-desa wilayah Kabupaten Luwu Timur bahwa desa memiliki kewenangan untuk mengurus pemerintahannya termasuk pengelolaan keuangan yang ada di APBDesa. Hal itu tertuang pada Peraturan Daerah Luwu Timur Nomor 06 Tahun 2008 tentang Penyerahan Urusan Pemerintahan Kabupaten kepada Desa .

Atas dasar inilah, maka penulis tertarik meneliti tentang Transparansi Pengelolaan Anggaran Pendapatan dan Belanja Desa di Desa Pertasi Kencana Kecematan Kalaena Kabupaten Luwu Timur karena dengan adanya transparansi maka diharapkan pengelolaan Anggaran Pendapatan dan Belanja desa di desa pertasi Kencana dapat berjalan secara maksimal agar tidak ada lagi penggelembungan dana yang tidak sesuai dengan program kerja desa

Transparansi adalah prinsip menciptakan kepercayaan timbal-balik antara pemerintah dan masyarakat melalui penyediaan informasi dan menjamin kemudahan didalam memperoleh Informasi adalah suatu kebutuhan penting masyarakat untuk berpartisipasi dalam pengelolaan daerah. Berkaitan dengan hal tersebut pemerintah daerah perlu proaktif memberikan informasi lengkap tentang kebijakan dan layanan yang disediakannya kepada masyarakat.

Pemerintah daerah seharusnya perlu menyiapkan kebijakan yang jelas tentang cara mendapatkan informasi. Kebijakan ini akan memperjelas bentuk informasi yang dapat diakses masyarakat ataupun bentuk informasi yang bersifat rahasia, bagaimana cara mendapatkan informasi, lama waktu mendapatkan informasi serta prosedur pengaduan apabila informasi tidak sampai kepada masyarakat. Instrumen dasar dari transparansi adalah peraturan yang menjamin hak untuk mendapatkan informasi, sedangkan instrumen pendukung adalah fasilitas database dan sarana informasi dan komunikasi dan petunjuk penyebarluasan produk-produk dan informasi yang ada di penyelenggara pemerintah, maupun prosedur pengaduan. Untuk itu adanya Perda Transparansi adalah sebagai produk hukum yang memberikan jaminan untuk mengatur tentang hak memperoleh akses dan penyebarluasan informasi kepada publik.. Meningkatnya kepercayaan masyarakat terhadap pemerintahan, maka akan menjamin meningkatnya jumlah masyarakat yang berpartisipasi dalam pembangunan daerahnya dan akan dapat meminimalisir berkurangnya pelanggaran /penyimpangan dalam pengelolaan pemerintahan. Luwu Timur telah mempunyai Perda Nomor 4 Tahun 2007 tentang Transparansi Penyelenggaraan Pemerintahan Luwu Timur. Hadirnya Perda Nomor 4 Tahun 3007 tentang Transparansi, hanya sekedar pelengkap dan penghibur agar dapat meredam suara-suara nyaring yangmendorong transparansi pemerintahan. Terlebih lagi, jangan-jangan hadirnya Perda tersebut, hanya sebagai bentuk justifikasi saja, bahwa pemerintahaan di Luwu Timur seakanakan telah berniat baik untuk, dan telah transparan. Sederhananya, Pemda memandang bahwa transparansi telah terlaksana ketika perdanya telah ada. Padahal, seperti yang kita ketahui, pola pikir yang terbangun di jajaran pengambilan kebijakan (Pemda dan Legislatif), terbiasa membuat Perda, tapi gagal dalam implementasi.

Transparansi adalah suatu proses keterbukaan dari para pengelolah manajemen, utamanya manajemen publik, untuk membangun akses dalam proses pengelolahan sehingga arus informasi keluar dan masuk berimbang. Jadi, dalam proses tranparansi informasi tidak hanya diberikan oleh pengelolahan manajemen public tapi masyarakat memiliki hak untuk memperoleh informasi yang menyangkut kepentingan public.

Sulistiyani (2004) menyatakan bahwa transparansi dan akuntabilitas adalah dua kata kunci dalam penyelenggaraan pemerintahan maupun penyelenggaraan perusahaan yang baik, dinyatakan juga bahwa dalam akuntabilitas terkandung kewajiban untuk menyajikan dan melaporkan segala 
kegiatan terutama dalam bidang administrasi keuangan kepada pihak yang lebih tinggi. Akuntabilitas dapat dilaksanakan dengan memberikan akses kepada semua pihak yang berkepentingan, bertanya atau menggugat pertanggungjawaban para pengambil keputusan dan pelaksana baik ditingkat program, daerah dan masyarakat. Anggaran Belanja Anggaran Pendapatan dan Belanja Daerah selanjutnya disingkat APBD adalah suatu rencana keuangan tahunan pemerintah daerah yang disetujui oleh Dewan Perwakilan Rakyat Daerah (UU No. 17 Tahun 2003 pasal 1 butir 8 tentang Keuangan Negara). Semua Penerimaan Daerah dan Pengeluaran Daerah harus dicatat dan dikelola dalam APBD. Penerimaan dan pengeluaran daerah tersebut adalah dalam rangka pelaksanaan tugastugas desentralisasi. Sedangkan penerimaan dan pengeluaran yang berkaitan dengan pelaksanaan Dekonsentrasi atau Tugas Pembantuan tidak dicatat dalam APBD.

APBD merupakan dasar pengelolaan keuangan daerah dalam satu tahun anggaran. APBD merupakan rencana pelaksanaan semua Pendapatan Daerah dan semua Belanja Daerah dalam rangka pelaksanaan Desentralisasi dalam tahun anggaran tertentu. Pemungutan semua penerimaan Daerah bertujuan untuk memenuhi target yang ditetapkan dalam APBD.

Tahun anggaran APBD sama dengan tahun anggaran APBN yaitu mulai 1 Januari dan berakhir tanggal 31 Desember tahun yang bersangkutan. Sehingga pengelolaan, pengendalian, dan pengawasan keuangan daerah dapat dilaksanakan berdasarkan kerangka waktu tersebut.

APBD disusun dengan pendekatan kinerja yaitu suatu sistem anggaran yang mengutamakan upaya pencapaian hasil kerja atau output dari perencanaan alokasi biaya atau input yang ditetapkan. Penganggaran pengeluaran harus didukung dengan adanya kepastian tersedianya penerimaan dalam jumlah yang cukup. Setiap pejabat dilarang melakukan tindakan yang berakibat pengeluaran atas beban APBD apabila tidak tersedia atau tidak cukup tersedia anggaran untuk membiayai pengeluaran tersebut.

\section{B. FUNGSI-FUNGSI ANGGARAN DAERAH}

Berdasarkan ketentuan dalam Pasal 3 ayat (4) UU No. 17 Tahun 2003 tentang Keuangan Negara, Fungsi APBD adalah sebagai berikut : (1) Fungsi Otorisasi : Anggaran daerah merupakan dasar untuk melaksanakan pendapatan dan belanja pada tahun yang bersangkutan (2) Fungsi Perencanaan : Anggaran daerah merupakan pedoman bagi manajemen dalam merencanakan kegiatan pada tahun yang bersangkutan. (3) Fungsi Pengawasan : Anggaran daerah menjadi pedoman untuk menilai apakah kegiatan penyelenggaraan pemerintah daerah sesuai dengan ketentuan yang telah ditetapkan. (4) Fungsi Alokasi : Anggaran daerah diarahkan untuk mengurangi pengangguran dan pemborosan sumber daya, serta meningkatkan efisiensi dan efektivitas perekonomian. (5) Fungsi Distribusi : Anggaran daerah harus mengandung arti/ memperhatikan rasa keadilan dan kepatutan. (6) Fungsi Stabilisasi : Anggaran daerah harus mengandung arti/ harus menjadi alat untuk memelihara dan mengupayakan keseimbangan fundamental perekonomian.

\section{KONSEP DESA}

Desa adalah suatu wilaya yang ditinggali oleh sejumlah orang yang saling mengenal, hidup bergotong ronyong , memiliki adat istiadatnya yang relatif sama, dan mempunyai tata cara sendiri dalam mengatur kehidupan kemasyarakatannya. Sebagian besar pencahariannya adalah bertani atau nelayan .

Menurut R. Bintarto (1968: 95) Desa adalah suatu perwujudan geografis yang ditimbulkan unsur-unsur fisiografis social ekonomis, politis, dan cultural yang terdapat disitu hubungan dan penaruh yang timbale balik denan daerah-daerah lain. Kemudian menurut PJ. Bournen (1971: 19) Desa adalah salah satu bentuk kuno dari kehidupan bersma sebayak beberapa ribu orang , hampir semuanya saling mengenal kebayakan yang termasuk di dalamnya hidup dari pertanian, perikanan, dan sebagainya usaha-usaha yang dapat dipengaruhi oleh hukum dan kehendak alam. Dan dalam tempat tinggal itu terdapat 
banyak ikatan-ikatan keluarga yang rapat, ketaatan, dan kaidah-kaidah social

Desa dihuni oleh masyaraka yang hidup dalam satu budya yang relative homogen Masyarakat desa terikat oleh kesamaan dan kestuan system nilai socialbudaya. Mereka bermasyarakat rukun dan guyub. Karna itu mereka disebut masyarakat paguyuban (gemeinschaft).

Wilaya pedesaan adalah wilaya yang jauh dari pusat ibukota kecamatan atau ibu kota kabupaten /kota. Penduduk desa pada umumnya berasal dari satu keturunan (geneologi) sehingga memiliki kekerabatan yang erat .Desa yang di dalamnya terdapat kesatuan masyarakat tesebut kemudian dilegalkan melalui UU No.32/2004 yang disebut sebagai kesatuan masyarakat hukum (adat).Kata desa berasal dari bahasa sansekerta yakni desi, dusun yang berarti tempat asal, tempat tinggal, negeri asal, atau tanah leluhur yang merujuk pada satu kesatuan hidup, dengan satu kesatuan norma, serta memiliki batas yang jelas.

Dalam upaya mendukung keberhasilan otonomi daerah terdapat tiga aspek utama yaitu pengawasan, pengendalian dan pemeriksaan. Ketiga hal tersebut pada dasarnya berbeda baik konsepsi maupun aplikasinya (Mardiasmo, 2002 : 213). Pengawasan mengacu pada tindakan atau kegiatan yang dilakukan oleh pihak luar (yang dipilih) untuk mengawasi kinerja pemerintah. Pengawasan dapat didefinisikan sebagai proses untuk " menjamin" bahwa tujuan-tujuan organisasimenjadi tercapai ini berkenaan dengan caracara membuat kegiatan sesuaidengan yang direncanakan (Handoko, 1996: 359). Sedangkan definisi pengawasan menurut Mockler (dalam Handoko, 1996 : 360) adalah pengawasan manajemen adalah suatu usaha sistematik untuk menerapkan standar pelaksanaan dengan tujuan perencanaan, merancang sistem informasi umpan balik, membandingkan kegiatan nyata dengan standar yang telah ditetapkan sebelumnya, menentukan dan mengukur penyimpanganpenyimpangan, serta mengambil tindakan koreksi yang diperlukan untuk menjamin bahwa semua sumber daya perusahaan dipergunakan dengan cara paling efektif dan efisien dalam pencapaian tujuan-tujuan perusahaan. Menurut Sujamto (1996 : 19)
"Pengawasan adalah segala usaha atau kegiatan untuk mengetahui dan menilai kenyataan yang sebenarnya mengenai pelaksanaan tugas dan kegiatan apakah sesuai dengan yang semestinya atau tidak". Dari pengertian di atas, pengawasan mempunyai kewenangan yang lebih "forcefull" terhadap objek yang dikendalikan, atau objek yang diawasi. Dalam pengendalian kewenangan untukmengadakan tindakan konkrit itu sudah terkandung di dalamnya, sedangkan dalam pengertian pengawasan tindakan korektif merupakan proses kelanjutan.

1. terbuka, mudah, dan dapat diakses oleh semua pihak yang membutuhkan serta disediakan secara memadai dan mudah dimengerti oleh masyarakat.

2. Terbuka dalam pengelolaan APBDesa adalah sistem pengembangan yang tidak dikoordinasi oleh suatu individu / lembaga pusat, tetapi oleh para pelaku yang bekerja sama dengan memanfaatkan kode sumber (source-code) yang tersebar dan tersedia bebas.

3. Kemudahan akses informasi adalah kemudahan mendapatkan informasi baik secara langsung maupun tidak langsung. Akses informasi secara langsung yaitu informasi yang didapatkan dengan langsung berhadapan dengan pihak terkait mengenai informasi yang dibutuhkan.

4. Bertanggung jawab adalah perwujudan kewajiban seseorang untuk mempertanggungjawabkan pengelolaan dan pengendalian sumberdaya dan pelaksanaan kebijakan yang di percayakan kepadaya dalam rangka pencapaian tujuan yang telah di tetapkan.

\section{METODE PENELITIAN}

Penelitian ini berlokasi pada Kantor Desa Pertasi Kencana Kecamatan Kalaena Kabupaten Luwu Timur. Pemilihan lokasi ini didasari pada pertimbangan transparasi pengelolaan APBDesa belum maksimal. Alasan lain dipilih sebagai tempat penelitian karena disamping Desa Pertasi Kencana tersebut mudah dijangkau oleh peneliti, objek penelitian juga terletak di desa tersebut.

Jenis penelitian yaitu penelitian kualitatif. Tipe 
penelitian ini menggunakan pendekatan deskriptif kualitatif. Berdasarkan penelusuran peneliti di lapangan, maka peneliti mengambil informan sebanyak 7 orang yang terbagi dalam: Kepala Desa 1orang, BPD 1 orang, Sekdes 1 orang, Kaur pemerintahan 1 orang masyarakat 3 orang, Jumlah 7 orang.

Data adalah catatan atas kumpulan fakta. Data merupakan bentuk jamak dari datum, berasal dari bahasa Latin yang berarti sesuatu yang diberikan. Dalam keilmuan (ilmiah), fakta dikumpulkan untuk menjadi data. Data kemudian diolah sehingga dapat diutarakan secara jelas dan tepat sehingga dapat dimengerti oleh orang lain yang tidak langsung mengalaminya sendiri, hal ini dinamakan deskripsi. Data Primer, Data primer adalah data yang diperoleh langsung dari sumber pertama. Data sekunder mencakup dokomen-dokumen resmi, buku-buku, hasil penelitian yang berwujud laporan dan sebagainya.

Sehubungan dengan pendekatan penelitian diatas, teknik pengumpulan data yang akan digunakan dalam penelitian ini adalahpenelitian lapangan (field research), dilakukan dengan cara mengunjungi langsung ke objek penelitian yaitu Kantor Desa Pertasi Kencana Kecamatan Kalaena Kabupaten Luwu Timur. Penelitian ini dilakukan melalui serangkaian kegiatan seperti: Observasi, yaitu melakukan pengamatan secara langsung pada objek penelitian terhadap aktivitas yang ada di Kantor Desa Pertasi Kencana Kecamatan Kalaena Kabupaten Luwu Timur. Wawancara, yaitu melakukan tanya-jawab dengan pihakpihak yang berhubungan dengan masalah penelitian yaitu kepala Desa dan masyarakat yang di Desa Pertasi Kencana Kecamatan Kalaena Kabupaten Luwu Timur.

Mereduksi data berarti merangkum, memilih hal-hal yang pokok, memfokuskan pada hal-hal yang penting, dicari tema dan polanya. Penyajian Data, dalam penelitian kualitatif, penyajian data merupakan rakitan informasi dalam bentuk uraian singkat, bagan, hubungan antar kategori, flowchart, dan sejenisnya agar makna peristiwa lebih mudah dipahami. Setelah menganalisis data, peneliti harus memastikan apakah interpretasi dan temuanpenelitian akurat.
Member checking, adalah proses peneliti mengajukan pertanyaan pada satu atau lebih partisipan untuk tujuan seperti yang telah dijelaskan di atas. Triangulasi merupakan proses penyokongan bukti terhadap temuan, analisis dan interpretasi data yang telah dilakukan peneliti yang berasal dari: (1) individu (informan) yang berbeda (guru dan murid), (2) tipe atau sumber data (wawancara, pengamatan dan dokumen),serta (3) metode pengumpulan data (wawancara, pengamatan dan dokumen).

\section{E. HASIL DAN PEMBAHASAN}

Transparansi adalah segala kegiatan yang dilaksanakan oleh penyelenggara pemerintah yang berkaitan dengan pendapatan, belanja, serta pembiayaan desa, sebagai upaya pemenuhan kebutuhan masyarakat berdasarkan peraturan perundang-undangan, yang bersifat terbuka, mudah, dan dapat diakses oleh semua pihak yang membutuhkan serta disediakan secara memadai dan mudah dimengerti oleh masyarakat.

Hasil penelitian dan wawancara kami terhadap transparansi pengelolaan APBDesa di Desa Pertasi Kencana Kecamatan Kalaena Kabupaten Luwu Timur, berikut hasil wawancara kami dengan kepala Desa Pertasi Kencana

"Kami selaku pemerintah sudah melaksanakan pengelolaan APBDesa sesuai dengan prosedur dan memberikan setiap masyarakat untuk memperoleh informasi tentang pelayanan pemerintahyang baik"

( wawancara, HM).

Hal senada juga disampaikan oleh ketua BPD desa Pertasi Kencana

"Bahwa setiap kita mengelolah APBDesa terkait dengan kepentingan masyarakat kami beserta kepalah desa menberikan informasi kepada masyarakat dengan jelas dan mengadakan musyawarah dengan masyarakat"(wawancara, SW.19).

Dari penjelasan di atas maka dapat kami simpulkan bahwa transparansi pengolaan APBDesa sudah berjalan dengan baik,dan merupakan perinsip keterbukaan 
yang mungkin masyarakat untuk mengetahui dan mendapatkan akses informasi yang seluas-luasnya tentang keuangan desa. Sesuai dengan pendapat Adrianto tanjung (2007:35) mengatakan transparansi adalah keterbukaan dan kejujuran kepada masyarakat berdasarkan pertimbangan bahwa masyarakat memiliki hak mengetahui secara terbuka dan meyeluruh atas pertanggungjawaban pemerintah dalam sumber daya yang dipercayakan kepadanya dan ketaatannya pada peraturan perundangundangan.

\section{Terbuka}

Dalam pengelolaan APBDesa adalah
sistem pengembangan yang tidak dikoordinasi oleh suatu individu / lembaga pusat, tetapi oleh para pelaku yang bekerja sama dengan memanfaatkan kode sumber (source-code) yang tersebar dan tersedia bebas.

Hasil penelitian dan wawancara kami terhadap keterbukaan pengelolaan APBDesa di Desa Pertasi Kencana Kecamatan Kalaena Kabupaten Luwu Timur, berikut hasil wawancara kami dengan kepala Desa Pertasi Kencana

"Dalam hal ini para aparat desa mestilah terbuka dalm melaksanakan pengelolaan Angaran Pendapatan dan Belanja Desa, desa Pertasi Kencana sudah melakukan yang demikian karena itu adalah suatu hal yang penting bagi masyarakat untuk mengetahuinya, keterbukaan dalam pelaksanaan APBDesa itu seperti diadakanya rapat dalam pengelolaan APBDesa ini memungkinkan para aparat memikirkan hal-hal yang dirapatkan, dan masyarakat dapat memberikan pendapatnya pula" (wawancara, HM).

Dari uraian dan penjelasan diatas di jelaskan bahwa keterbukaan bagi masyarakat sangatlah penting, agar dalam musyawarah masyarakat dapat di beri kesempatan untuk memberikan pendapatnya pula sehingga halhal yang di rapatkan dapat di ketahui oleh masyarakat luas di daerah tersebut

Hasil penelitian dan wawancara kami terhadap keterbukaan pengelolaan
APBDesa di Desa Pertasi Kencana Kecamatan Kalaena Kabupaten Luwu Timur, berikut hasil wawancara kami dengan BPD desa Pertasi Kencana

"Kami selaku BPD melihat penelolaan Anggaran Pendapatan dan Belanja desa Pertasi Kencana terbuka, artinya dalam pengelolaan APBDesa tidak ada yang di tutup-tutupi begitu pula pembuatan Rancangan peraturan desa yang telah di setujui bersama oleh kepalah desa dan BPD disampaikan oleh pimpinan kepada kepala Desa untuk ditetapkan menjadi peraturan desa, dengan keterbukaan penyampaian rancangan peraturan desa dilakukan dalam jangka waktu 7 (tuju) hari sejak tanggal persetujuan bersama"(wawancara, SN).

Dari uraian dan penjelasan diatas di jelaskan bahwa pengelolaan APBDesa terbukaan bagi masyarakat dan tidak ada yang di tutup-tutupi sehingga pengelolaan APBDesa, dapat diketahui oleh masyarakat luas dan masyarakat juga dilibatkan dalam musyawarah.

Hasil penelitian dan wawancara kami terhadap keterbukaan pengelolaan APBDesa di Desa Pertasi Kencana Kecamatan Kalaena Kabupaten Luwu Timur, berikut hasil wawancara kami dengan Sekdes Pertasi Kencana

"Dalam menyusun dan melaksanakan APBDesa keterbukaan sudah berjalan sebagamana mestinya begitu juga kebijakan pengelolaan APBDesa dan menyusun raperdes APBDesa, perubahan APBDesa dan pertanggung jawaban pelaksanan APBDesa serta menyusun rancangan keputusan kepala desa tentang pelaksanaan peraturan desd" (wawancara, $\mathrm{AH}$ ).

Dari penjelasan di atas maka dapat kami simpulkan bahwa tranparansi pengolaan APBDesa terbuka dan berjalan sebagaimana mestinya.

Hasil penelitian dan wawancara kami terhadap keterbukaan pengelolaan APBDesa di Desa Pertasi Kencana Kecamatan Kalaena Kabupaten Luwu Timur, berikut hasil wawancara kami dengan Kaur Pemerintahan desa Pertasi Kencana: 
"Pada prinsipnya dalam keterbukaan pemerataan dan keadilan masyarakat berdasarkan perinsip-perinsip terebut desa diatur sebagai dan dikembalikan sebagai masyarakat hukum yang berwenang mengatur dan mengurus urusan masyarakat setempat sebagai perwakilan rakyat yang berfungsi sebagai pengayom masyarakat disamping sebagai nomenklatur desa yg berkedudukan di desa" (wawancara, SM).

Hasil penelitian dan wawancara kami terhadap keterbukaan pengelolaan APBDesa di Desa Pertasi Kencana Kecamatan Kalaena Kabupaten Luwu Timur, berikut hasil wawancara kami dengan Masyarakat desa Pertasi Kencana

"Kami selaku masyarakat desa pertasi kencana melihat pengelolaan APBDesa di Desa Pertasi Kencana kurang keterbukan karna kurangnya sosialisasi yang dilakukan oleh aparat desa sehingga kami kurang mengetahui pengelolaan APBDesa"

(wawancara, IW).

Dari penjelasan di atas maka dapat kami simpulkan bahwa tranparansi pengolaan APBDesa kurang keterbukaan karna tidak semua informasi di informasikan Pelaksanaan kegiatan-kegiatan yang pembiayaannya bersumber dari APBDesa kurang transparansi.

Hasil penelitian dan wawancara kami terhadap keterbukaan pengelolaan APBDesa di Desa Pertasi Kencana Kecamatan Kalaena Kabupaten Luwu Timur, berikut hasil wawancara kami dengan Masyarakat desa Pertasi Kencana

"Saya selaku masyarakat Desa Pertasi Kencana memberi apresiasi kepada kepala pemerintah desa dan para aparatnya dalam melakukan pengelolaan APBDesa secara terbuka dan transparan kepada masyarakat sehingga tingkat kepercayaan kami kepada pemerintah desa sangat tinggi"

( wawancara, RM).

Dari penjelasan di atas maka dapat kami simpulkan bahwa tranparansi pengolaan APBDesa terbuka sebagaimana layaknya desa-desa yang ada di Kecamatan Kalaena karena hasil penelitian dan wawancara kami terhadap keterbukaan pengelolaan APBDesa di Desa Pertasi Kencana Kecamatan Kalaena Kabupaten Luwu Timur, berikut hasil wawancara kami dengan Masyarakat desa Pertasi Kencana

"Saya selaku masyarakat Desa Pertasi melihat pengelolaan APBDesa berjalan sebagamana mestiya sama dengan desa-desa yang lain yang ada di Kecamatan Kalaena semua melakukan pengelolaan APBDesa secara terbuka tidak ada peyimpangan, sehingga pembangunan berjalan lancar" (wawancara,SK).

Dari uraian dan penjelasan diatas di jelaskan bahwa pengelolaan APBDesa terbuka karena sudah berjalan sesuai dengan prosedur namun masih perlu ditingkatkan.

\section{Kemudahan akses}

Kemudahan akses informasi adalah kemudahan mendapatkan informasi baik secara langsung maupun tidak langsung. Akses informasi secara langsung yaitu informasi yang didapatkan dengan langsung berhadapan dengan pihak terkait mengenai informasi yang dibutuhkan. Informasi tidak langsung adalah informasi yang didapatkan melaui media perantara seperti penggunaan IT, pengumuman lewat brosur, pamplet dan lain-lain.

Hasil penelitian dan wawancara kami terhadap kemudahan diakses dalam pengelolaan APBDesa di Desa Pertasi Kencana Kecamatan Kalaena Kabupaten Luwu Timur, berikut hasil wawancara kami dengan kepala Desa Pertasi Kencana

"Kami selaku pemerintah desa dalam pemberian informasi memudahkan untuk diakses semaksimal mungkin itu di buktikan dengan adanya papan informasi yang kami sediakan di dalam kantor desa, karena kami selaku pemerintah desa senantiasa siap menberikan informasi yang di butuhkan oleh masyarakat"( wawancara, HM). 
Dari penjelasan di atas maka dapat kami simpulkan bahwa kemudahan akses pengolaan APBDesa mudah karna aparat desa menyediakan papan informasi di kantor desa sehingga masyarakat muda untuk mengakses

Hasil penelitian dan wawancara kami terhadap kemudahan akses dalam pengelolaan APBDesa di Desa Pertasi Kencana Kecamatan Kalaena Kabupaten Luwu Timur, berikut hasil wawancara kami dengan BPD desa Pertasi Kencana

"Tanggapan kami mengenai pengolaan APBDesa itu mudah diakses karena tiap tahunnya kami melakukan perubahan APBDesa, dan kepalah desa dengan aparatnya kami punya data-data perubahanAPBDesa jadi jika ada yang membutuhkannya kami bisa menperlihatkan rincian-rincian dana dan tidak ada yang di tutup-tutupi"'(wawancara, SN).

Dari penjelasan di atas maka dapat kami simpulkan bahwa kemudahan akses pengolaan APBDesa mudah karna informasi ada selalu diapdet dan tidak ada yang ditutup-tutupi.

Hasil penelitian dan wawancara kami terhadap kemudahan dalam pengelolaan APBDesa di Desa Pertasi Kencana Kecamatan Kalaena Kabupaten Luwu Timur, berikut hasil wawancara kami dengan Sekdes Pertasi Kencana

"Bahwasanya pengelolaan APBDesa itu mudah di akses karena rincian rincian dana semua tertulis pada perubahan anggaran pendapatan dan belanja desa" (wawancara, $\mathrm{AH}$ ).

Dari penjelasan di atas maka dapat kami simpulkan bahwa kemudahan akses pengolaan APBDesa mudah diakses karena informasi tentang dana tidak ada yang ditutupi.dan bisa diakses.

Hasil penelitian dan wawancara kami terhadap kemudahan diakses dalam pengelolaan APBDesa di Desa Pertasi Kencana Kecamatan Kalaena Kabupaten Luwu Timur, berikut hasil wawancara kami dengan Kaur Pemerintahan desa Pertasi Kencana,
"Pada prinsipnya dalam kemudahan akses pengelolaan APBDesa pemerataan dan keadilan masyarakat berdasarkan perinsipperinsip hukum desa yang berwenang mengatur dan mengurus urusan masyarakat setempat sebagai perwakilan rakyat yang berfungsi sebagai pengayom masyarakat yg berkedudukan di desa"( wawancara, SM).

Dari penjelasan di atas maka dapat kami simpulkan bahwa kemudahan akses pengolaan APBDesa mudah ,karena sudah sesuai dengan perundang undang an yang berlaku.

Hasil penelitian dan wawancara kami terhadap kemudahan di akses dalam pengelolaan APBDesa di Desa Pertasi Kencana Kecamatan Kalaena Kabupaten Luwu Timur, berikut hasil wawancara kami dengan Masyarakat desa Pertasi Kencana

"Sepengetahuan kami selama ini pengelolaan APBDesa mudah diakses atau mudah diketahui karna biasanya kepala desa menyampaikan biaya-biaya pembangunan yang akan dilaksanakan dan yang sudah dilaksanakan, dan anggaran yang sudah dipakai dan anggaran yang akan dipakai" (wawancara, IW).

Dari penjelasan di atas maka dapat kami simpulkan bahwa kemudahan akses pengolaan APBDesa mudah karena ada memberikan informas kepada siapapun masyarakat yang ingin mengetahuinya.

Hasil penelitian dan wawancara kami terhadap kemudahan di akses dalam pengelolaan APBDesa di Desa Pertasi Kencana Kecamatan Kalaena Kabupaten Luwu Timur, berikut hasil wawancara kami dengan Masyarakat desa Pertasi Kencana

"Kami tidak tau tentang pengelolaan APBDesa karena kami selaku masyarakat biasa jarang pergi ke kantor desa ,kami hanya melaksanakan kewajiban sebagai masyarakat "(wawancara, RM)

Dari penjelasan di atas maka dapat kami simpulkan bahwa kemudahan akses pengolaan APBDesa masih kurang dirasakan oleh masyarakat bawah. 
Hasil penelitian dan wawancara kami terhadap kemudahan diakses dalam pengelolaan APBDesa di Desa Pertasi Kencana Kecamatan Kalaena Kabupaten Luwu Timur, berikut hasil wawancara kami dengan Masyarakat desa Pertasi Kencana

"Kami selaku warga dan masyarakat desa pertasi kencana melihat pengelolaan APBDesa selama ini mudah diakses ,namun masih perlu di permudah lagi agar masyarakat luas bisa lebih mengetahui,karena selama ini teknologi belum di gunakan semaksimal mungkin contohnya desa pertasi kencana tidak memilikii websait desa ,sekiranya memilki websait masyarakat sangat mudah untuk menperoleh informasi tentang desa tersebut" (wawancara, SK)

Dari uraian dan penjelasan diatas di jelaskan bahwa pengelolaan APBDesa mudah diakses oleh masyarakat sehingga pengelolaan APBDesa, dapat di ketahui oleh masyarakat luas di daerah tersebut.

\section{Dapat diakses}

Suatu keadaan dimana sistem pengembangan informasi tersebar dan tersedia bebas atau prinsip yang menjamin akses atau kebebasan bagi setiap orang untuk memperoleh informasi tentang penyelenggaraan pemerintah, yakni informasi tentang kebijakan, proses pembuatan dan pelaksanaannya, serta hasilhasil yang dicapai.

Hasil penelitian dan wawancara kami terhadap pengelolaan APBDesa di Desa Pertasi Kencana Kecamatan Kalaena Kabupaten Luwu Timur dengan indikato dapat diakses, berikut hasil wawancara kami dengan kepala Desa Pertasi Kencana
"bukan hanya mengatur tentang hak public untuk mendapatkan informasi, tetapi juga menekankan pada aparat pemerintah untuk memfasilitasi akses tersebut. Kami mengacu pada aturan yang ada bahwa sebuah kantor pemerintahan harus mempublikasikan informasi yang berhubungan dengan :struktur, fungsi dan operasi, kinerja yang dihasilkan oleh organisasi

tersebut"( wawancara, HM).

Dari uraian dan penjelasan diatas di jelaskan bahwa pemberian informasi bagi masyarakat sangatlah penting dan pasilitas untuk mengetahui informasi,agar dalam masyarakat tidak terjadi kesimpansiuran tentang kinerja aparat desa.

Hasil penelitian dan wawancara kami terhadap pengelolaan APBDesa di Desa Pertasi Kencana Kecamatan Kalaena Kabupaten Luwu Timur dengan indikato dapat diakses, berikut hasil wawancara kami dengan BPD desa Pertasi Kencana

"Kami selaku BPD melihat penelolaan
Anggaran Pendapatan dan Belanja desa
Pertasi Kencana dapat diakses, artinya
dalam pengelolaan APBDesa masyarakat
dapat mengakses informasi baik secara
lisan maupun melalui media"( wawancara,
SN).

Dari uraian dan penjelasan diatas di jelaskan bahwa pengelolaan APBDesa dapat diakses oleh masyarakat karna masyarakat mudah mendapatkan informasi sehingga pengelolaan APBDesa, dapat di ketahui oleh masyarakat luas di daerah tersebut

Hasil penelitian dan wawancara kami terhadap pengelolaan APBDesa di Desa Pertasi Kencana Kecamatan Kalaena Kabupaten Luwu Timur dengan indikato dapat diakses, berikut hasil wawancara kami dengan Sekdes Pertasi Kencana

"Apa yang di lakukan pemerintah desa Pertasi Kencana dalam hal transparans penelolaan APBDesa dapat diakses, karena dilakukan dengan terbuka atau transparan untuk semua kalangan. penyediaan informasi yang jelas tentang prosedur-prosedur pengelolaan keuangan itu dilakukan perperiodik dan sifatnya terbuka termasuk jika prosedur-prosedur itu sewaktuwaktu berubah atau terganti"(wawancara, AH). 
Dari uraian dan penjelasan diatas di jelaskan bahwa pengelolaan APBDesa Informasi tersebut menunjukkan adanya penerapan Azas transparansi dalam perencanaan ADD dan APBDesa yang dapat diketahui oleh masyarakat secara umum.

Hasil penelitian dan wawancara kami terhadap pengelolaan APBDesa di Desa Pertasi Kencana Kecamatan Kalaena Kabupaten Luwu Timur dengan indikato dapat diakses, berikut hasil wawancara kami dengan Kaur Pemerintahan desa Pertasi Kencana:

"Kesan tidak dapat diakses itu mungkin akan ada peluang dari arus bawa untuk mencurigai adanya penyimpangan. Sehingga transparansi harus dilakukan secara utuh dan dengan komitmen yang kuat baik secara pribadi maupun secara bersama-sama dalam satu kelompok kerja dengan memadukan segala perbedaan dan satu persepsi"(wawancara, SM).

Dari uraian dan penjelasan diatas di jelaskan bahwa pengelolaan APBDesa dapat diakses oleh masyarakat secara umum namun masyarakat bawa susah untuk mendapatkan informasi.

Hasil penelitian dan wawancara kami terhadap pengelolaan APBDesa di Desa Pertasi Kencana Kecamatan Kalaena Kabupaten Luwu Timur dengan indikator dapat diakses, berikut hasil wawancara kami dengan Masyarakat desa Pertasi Kencana

"Saya rasa Pemerintah Desa Pertasi Kencana telah melakukan langkahlangkah pertanggung jawaban dengan cara yang terbuka salah satunya adalah penyedian papan informasi yang dapat diakses namun informasi yang diberikan harus akurat dan lengkap"(wawancara, IW).

Dari uraian dan penjelasan diatas di jelaskan bahwa pengelolaan APBDesa dapat diakses namun dari pihak masyarakat mengatakan bahwa informasinya biasa kurang update itu dikarenakan kadang informasinya lambat di publikasikan.
Hasil penelitian dan wawancara kami terhadap pengelolaan APBDesa di Desa Pertasi Kencana Kecamatan Kalaena Kabupaten Luwu Timur dengan indikato dapat diakses, berikut hasil wawancara kami dengan Masyarakat desa Pertasi Kencana

"Saya selaku masyrakat Desa Pertasi Kencana melihat Informasi yang dapat kita akses mengenai pengelolaan keuangan desa melalui papan informasi dapat diakses namun kadang lambat informasinya "(wawancara, RM)

Dari uraian dan penjelasan diatas di jelaskan bahwa pengelolaan APBDesa azas akuntabel dan azas partisipatif administrasi keuangan di Desa Pertasi kencana belum sepenuhnya dapat di akses oleh masyarakat secara umum karena kadang informasinya lambat .

Hasil penelitian dan wawancara kami terhadap pengelolaan APBDesa di Desa Pertasi Kencana Kecamatan Kalaena Kabupaten Luwu Timur dengan indikator dapat diakses, berikut hasil wawancara kami dengan Masyarakat desa Pertasi Kencana.

"Saya selaku masyarakat Desa Pertasi melihat pengelolaan APBDesa berjalan sebagamana mestiya sama dengan desa-desa yang lain yang ada di Kecamatan Kalaena semua melakukan pengelolaan APBDesa secara terbuka dan dapat diakes tidak ada peyimpangan, sehingga pembangunan berjalan lancar" (wawancara, SK).

Dari uraian dan penjelasan diatas di jelaskan bahwa pengelolaan APBDesa dapat diakses oleh masyarakat, karena penyediaan informasi yang jelas tentang prosedur-prosedur pengelolaan keuangan namun masih perlu ditingkatkan.

\section{Bertanggung jawab}

Bertanggung jawab adalah perwujudan kewajiban seseoranguntuk mempertanggungjawabkan pengelolaan dan pengendalian sumberdaya dan pelaksanaan kebijakan yang di percayakan kepadanya dalam rangka pencapaian tujuan yang 
telah di tetapkan.

Hasil penelitian dan wawancara kami dalam bertanggung jawab terhadap pengelolaan APBDesa di Desa Pertasi Kencana Kecamatan Kalaena Kabupaten Luwu Timur, berikut hasil wawancara kami dengan kepala Desa Pertasi Kencana

"Kami membuat laporan keuangan hem dan papan informasi dikantor desa yang memuat seluruh rencana penggunaan $A D D$ dan APBDesa dan danadana lain yang dikelola oleh pemerintah desa. Hal tersebut untuk memberikan informasi kepada siapapun masyarakat yang ingin mengetahuinya. Jadi nanti dalam mempertanggung jawabkan kami juga tidak begitu repot."(wawancara, HM).

Dari uraian dan penjelasan diatas di jelaskan bahwa pengelolaan APBDesa. Sudah berdasarkan pada prinsip tanggungjawab, dan sesuai dengan ketentuan yang ada. Hasil penelitian dan wawancara kami dalam bertanggung jawab terhadap pengelolaan APBDesa di Desa Pertasi Kencana Kecamatan Kalaena Kabupaten Luwu Timur, berikut hasil wawancara kami dengan BPD desa Pertasi Kencana

"Tanggapan kami mengenai pengolaan APBDesa itu bertanggungjawab, karena tiap enam bulan sekali kami melakukan evaluasi bersama masyarakat dan kepala desa tentang pelaksanaan kami APBDesa, dan tiap tahun diadakan perubahan APBDesa dan data-data perubahanAPBDesa disajikan di papan informasi jadi jika ada yang membutuhkannya kami bisa menperlihatkan rincian-rincian dana dan tidak ada yang di tutup-tutupi"'(wawancara, SN).

Dari uraian dan penjelasan diatas di jelaskan bahwa pengelolaan APBDesa bertanggung jawab dengan adanya keterlibatan masyarakat dalam perencanaan dari penggunaan dana APBDes melalui suatu rapat yang disebut Musyawarah Perencanaan Pembangunan Desa.

Hasil penelitian dan wawancara kami dalam bertanggung jawab terhadap pengelolaan APBDesa di Desa Pertasi Kencana Kecamatan Kalaena
Kabupaten Luwu Timur, berikut hasil wawancara kami dengan Sekdes Pertasi Kencana

"Pelaksanaan APBDesa ditempuh melalui sistem pelaporan yaitu laporan bulanan dan laporan masing-masing tahapan kegiatan Sistem pelaporan dilaksanakan secara berjenjang, dari Tim Pelaksana Kegiatan tingkat Desa ke Tim Fasilitasi Tingkat Kecamatan dan Tim Fasilitasi Kecamatan ke Tingkat Kabupaten dengan menggunakan format yang telah ditetapkan, pelaporan tersebut dilaksanakan secara rutin, setiap bulan dan setiap akhir pelaksanaan tahapan kegiatan."(wawancara, $\mathrm{AH}$ ).

Dari uraian dan penjelasan diatas di jelaskan bahwa pengelolaan APBDesa bertanggung jawab karna setiap pelaksanan APBDesa melalui sistem pelaporan dan ada laporan pertanggung jawaban setelah melakukan kegiatan yang berkaitan dengan APBDesa.

Hasil penelitian dan wawancara kami dalam bertanggung jawab terhadap pengelolaan APBDesa di Desa Pertasi Kencana Kecamatan Kalaena Kabupaten Luwu Timur, berikut hasil wawancara kami dengan Kaur Pemerintahan desa Pertasi Kencana:

"hal senada juga disampaikan oleh SM bahwa pengelolaan APBDesa Pertanggungjawaban pelaksanaan program ADD dan APBDesa kepada pemerintah tingkat atasnya dilakukan melalui sistem pelaporan yang dilakukan secara periodik. "(wawancara, SM).

Dari uraian dan penjelasan diatas di jelaskn bahwa pengelolaan APBDesa itu bertanggung jawab karena semuanya berjalan sebagaimana mestinya seusui dengan aturan yang ada.

Hasil penelitian dan wawancara kami dalam bertanggung jawab terhadap pengelolaan APBDesa di Desa Pertasi Kencana Kecamatan Kalaena Kabupaten Luwu Timur, berikut hasil wawancara kami dengan Masyarakat desa Pertasi Kencana

"Kami selaku masyarakat desa pertasi kencana melihat pengelolaan APBDesa di 
Desa Pertasi Kencana bertanggung jawab karna sumua hal-hal berkaitan dengan pengelolaan keuangan disosialisasi yang dilakukan oleh aparat desa sehingga kami mengetahui pengelolaan APBDesa "C wawancara dari IW).

Dari uraian dan penjelasan diatas di jelaskan bahwa pengelolaan APBDesa parat desa mensosialisasikan kepada masyarakat dan itu termasuk pertanggun jawaban.

Hasil penelitian dan wawancara kami dalam bertanggung jawab terhadap pengelolaan APBDesa di Desa Pertasi Kencana Kecamatan Kalaena Kabupaten Luwu Timur, berikut hasil wawancara kami dengan Masyarakat desa Pertasi Kencana.

"Dalam hal pelaksanaan program APBDes juga harus menjunjung tinggi prinsip partisipatif dalam pengambilan keputusan dan tranparansi, tetapi hal tersebut masih belum maksimal telaksana dengan sebagaimana harapan yang dinginkan masyarakat" (wawancara, RM)

Dari uraian dan penjelasan diatas di jelaskan bahwa pengelolaan APBDesa bertanggung jawab namun masih perlu ditingkatkan lagi karna masyarakat belum merasa puas.

Hasil penelitian dan wawancara kami dalam bertanggung jawab terhadap pengelolaan APBDesa di Desa Pertasi Kencana Kecamatan Kalaena Kabupaten Luwu Timur, berikut hasil wawancara kami dengan Masyarakat desa Pertasi Kencana

"Saya selaku masyarakat Desa Pertasi melihat pengelolaan APBDesa berjalan sebagamana mestiya sama dengan desa-desa yang lain yang ada di Kecamatan Kalaena semua melakukan pengelolaan APBDesa secara bertanggung jawab tidak ada peyimpangan, sehingga pembangunan berjalanlancar" (wawancara,SK).

Dari uraian dan penjelasan diatas di jelaskan bahwa pengelolaan APBDesa di Desa Pertasi Kencana Kecamatan Kalaena Kabupaten Luwu Timur bertanggung jawab, karena dalam musyawarah masyarakat dapat di beri kesempatan untuk memberikan pendapatnya pula sehingga hal-hal yang di rapatkan dapat di ketahui oleh masyarakat luas di daerah tersebut.

\section{Faktor-faktor yang mempengaruhi}

Telah dikaji dalam penelitian mengenai APBDesa. Dari pembahasan tersebut dapat diketahui bahwa Implementasi Pengelolaan dan Penatausahaan Keuangan Desa berdasarkan Peraturan desa pertasi kencana N0. 04 Tahun2013 Tentang Keuangan Desa di Desa Pertasi kencana yang diketahui sudah berjalan dengan cukup baik namun tidak serta merta berjalan mulus, di balik itu semua terdapat hal yang dinamakan hambatan dan pendorong. Faktor yang mempengaruhi dalam pelaksanaan pengelolaan APBDesa, terutama di tingkat implementasi di desa Pertasi Kencana. Faktor penghambat yang dapat diidentifikasikan mencakup:

Sosialisasi kepada masyarakat mengenai pengelolaan APBDesa dipandang belum memadai karena hanya dilakukan pada perangkat pelaksana, sehingga pemahaman masyarakat mengenai APBDesa kurang, hal ini akan berakibat pada sulitnya mengajak partisipasi masyarakat dalam pelaksanaan pengelolaan APBDesa maupun dalam pengawasan kegiatan terutama pengawasan oleh masyarakat.

Berikut hasil wawancara dengan masyarakat terkait Sosialisasi pengelolaan APBDesa

"sosialisasi yang dilakukan aparat desa belum memadai dikarnakan pemerintah kurang kreatif dalam mensosialisasikan pengelolaan APBDesa karena selama ini belum dïmplementasikan teknologi internet jejaring sosial untuk mensosialisasikannya " (wawancara, HT)

Penerapan teknologi dalam pemerintahan bisa memudakan masyarakat dan pemerintah dalam penyelenggaraan pemerintahan salah satu contohnya sekarang sudah diterapkan yang namanya E-KTP.

Sementara itu masih terdapat kelemahan dalam hal sumber daya manusia dimana tingkat kemampuan pelaksana tidak merata, yaitu secara pendidikan masih rendah sehingga mempengaruhi kemampuan mengidentifikasi dan menyelesaikan 
masalah dengan cepat Namun hal ini tidak mempengaruhi pelaksanaan APBDesa karena adanya kemampuan untukmenggerakkan masyarakat.

Berikut hasil wawancara dengan masyarakat terkait dengan kapasitas Sumber Daya Manusia dalam pengelolaan APBDesa

"untuk dapat melaksanakan pengeloaan Anggaran Pendapatan dan Belanja Desa (APBDesa) secara maksimal harus didukung dengan Sumber Daya Manusiayang memadai dalam kaitannya dengan Sumber Daya Manusia berpusat pada rendanya tingkat pendidikan para pengelola APBDesa"( wawancara, $\mathrm{HL}$ )

Kaitannya dengan sumber daya manusia berpusat pada rendahnya pendidikan para pelaksana pengelolaan APBDesa, sehingga pemahaman pelaksana mengenai APBDesa kurang, serta tidak adanya dukungan yang memadai. Hal ini menimbulkan kurangnya dukungan pengawasan, terutama pengawasan oleh masyarakat.

Sebagaimana telah dibahas pada bagian sebelumnya peran serta masyarakat dinilai kurang memadai akibat kurangnya sosialisasi yang ditujukan bagi masyarakat. Hal ini menyebabkan masyarakat baik secara individu maupun melalui kelembagaan kurang memahami peran serta tugasnya. Dalam hal ini pemahaman masyarakat adalah membantu pelaksanaan secara fisik dari berbagai kegiatan implementasi, pengelolaan APBDesa kondisi tersebut menyebabkan tidak ada peningkatan kapasitas masyarakat/ lembaga masyarakat yang akhirnya menyebabkan rendahnya peran pengawasan oleh masyarakat.

Peningkatan kemampuan lembaga kemasyarakatan di desa dalam perencanaan, pelaksanaan dan pengendalian pembangunan tidak tercapai optimal, karena lembaga kemasyarakatan hanya dilibatkan dalam penyusunan rencana kegiatan dan pelaksanaan fisik. Sementara itu dalam pelaksanaan dan pengendalian dan proses administratiftidak dilibatkan.

Peningkatan partisipasi swadaya masyarakat dalam program-program lapangan yang dibiayai APBDesa juga belum optimal khususnya dalam hal pembiayaan. Berdasarkan data yang penulis peroleh dilapangan total pembiayaan partisipatif dari masyarakat mencapai $12,53 \%$ dari total dianggarkan untuk pembiayaan daerah, sebesar Rp. 945.056.000,sementara sisanya berasal dari ADD. Belum optimalnya partisipasi swadaya masyarakat ini dikarenakan karena kondisi perekonomian masyarakatyangkurangmendukung.

Kapasitas Aparatur Desa sebagai pelaksana kebijakan menjadi faktor penunjang keberhasilan pelaksanaan program-program yang dibiayai APBDesa. Kemampuan dan keterampilan Aparatur Desa sebagai pelaksana kebijakan merupakan dasar dari Pelaksanaan Pemerintahan khususnya di Bidang Keuangan dalam mengelola APBDesa Dari hasil penelitian dalam hubungan sumber daya dengan pelaksanaan AAPBDesa, terdapat beberapa faktor penting sebagai pendorong. Beberapa faktor pendorongtersebutadalah:

a) Kemampuan pelaksana untuk memberi dorongan kepada masyarakat agar berpartisipasi dalam kegiatan APBDesa, meskipun hanya berupa tenaga dan material.

b) Adanya kemampuan pelaksana kebijakan APBDesa dalam melakukan identifikasi dan menyelesaikan masalah dalam pelaksanaan APBDesa.

c) Kelengkapan sarana/prasarana desa dalam mendukung kebijakan APBDesa.

\section{F. PENUTUP}

Berdasarkan hasil penelitian yang dilakukan maka penulis menyimpulkan sebagai berikut:

Transparansi Pengelolaan Anggaran Pendapatan dan Belanja Desa dengan indikator; (1) keterbukaan, Berdasarkan hasil pengamatan penulis bahwa Pengelolaan Anggaran Pendapatan dan Belanja Desa terbuka namun masih perlu ditingkatkan kejelasan prosedur-prosedur dan kejelasan biaya-biaya belum maksimal transparan. (2) Kemudahan akses informasi dengan indikator kemudahan mendapatkan informasi langsung maupun tidak langsung bisa dikatakan cukup mudah. (3) Dapat diakses, Hasil penelitian dan wawancara kami terhadap pengelolaan APBDesa di Desa Pertasi Kencana Kecamatan Kalaena Kabupaten Luwu Timur dengan indikato dapat diakses, dapat diakses namun belum maksimal. (4) Bertanggung jawab. Hasil penelitian dan wawancara kami terhadap pengelolaan APBDesa di Desa Pertasi Kencana Kecamatan Kalaena Kabupaten Luwu Timur dengan indikato Bertanggung jawabsudah terlaksana karena masyarakat dilibatkan dalam rapar.

Berdasarkan kesimpulan dari hasil penelitian yang telah dikemukakan di atas, 
maka dapat diberikan saran-saran yang nantinya di harapkan dapat memperbaiki ataupun menyempurnakan pelaksanaan Transparansi Pengelolaan di Desa Pertasi Kencana Kecamatan Kencana Kabupaten Luwu Timur di masa akan datang. Saran-saran dimaksud adalah : (1) Sosialisasi terhadap kebijakan Transparansi Pengelolaan diberikan kepada masyarakat luas sehingga setelah memahami kebijakan Transparansi Dana Desa, masyarakat juga akan lebih mudah untuk diajak berpartisipasi dalam pelaksanaan TransparansiDana Desa, ikut melestarikan hasil pelaksanaan Transparansi Pengelolaan serta ikut mengawasi jalannya Transparansi Pengelolaan sesuai dengan ketentuan yang ada. (2) Para pelaksana Transparansi Pengelolaan diberikan peningkatan pengetahuan melalui pendidikan dan latihan, khususnya yang menyangkut pengelolaan keuangan desa. Sedangkan untuk mempercepat pembuatan laporan pelaksanaan Transparansi Pengelolaan serta mengurangi kesalahan dalam pembuatan dokumen, perlu dibangunnya sistem aplikasi komputer yang memungkinkan akurasi dan kecepatan data.

\section{DAFTAR PUSTAKA}

Madani, Mukhlis, dkk. 2013. Pedoman Penulisan Proposal Penelitian dan Skripsi. Makassar.

Mohadir, Noeng. 1999. Metode Penelitian Kualitatif. Yogyakarta : Rake Sarasin

Mohtar, Mas'oed. 1994. Politik, Birokrasi, dan Pembangunan. Yogyakarta : Pustaka Pelajar

Nurcholis, Hanif. 2011. Pertumbuhan \& penyelenggaraan pemerintahan desa. Jakarta : Erlangga.

Rewansyah, Asmawi. 2010. Reformasi Birokrasi Dalam Rangka Good Governance. Jakarta : CV Yusaintanas Prima

Sugiyono. 2012. Memahami Penelitian Kualitatif. Bandung : Alfabeta

Syakrani, 2009. Good Governance. Yogyakarta : Pustaka Pelajar
Thoha, Miftah. 2003. Birokrasi dan Politik di Indonesia. Jakarta : PT Raja Grafindo Persada

Widjaja, HAW. 2003 Otonomi Desa. Bukit Besar : Rajawali Pers

Peraturan Daerah Kabupaten Luwu Timur Nomor 06 Tahun 2008 Tentang Penyerahan urusan pemerintahan Kabupaten Kepada Desa

$* * * * * * * * *$ 